\title{
The Role of Physical and Political Factors on the Conservation of Native Vegetation in the Brazilian Forest-Savanna Ecotone
}

\author{
Henrique O. Sawakuchi ${ }^{1}$, Maria Victoria R. Ballester ${ }^{1}$, Manuel Eduardo Ferreira ${ }^{2}$ \\ ${ }^{1}$ Center of Nuclear Energy in Agriculture, University of São Paulo, Piracicaba, Brazil \\ ${ }^{2}$ Social-Environmental Studies Institute/LAPIG, Federal University of Goiás, Goiânia, Brazil \\ Email: henrique.sawakuchi@usp.br
}

Received September $6^{\text {th }}, 2012$; revised October $18^{\text {th }}, 2012$; accepted October $29^{\text {th }}, 2012$

\begin{abstract}
The Araguaia River Basin covers a considerable extent of Brazilian Savanna (locally called Cerrado) and part of Amazon Tropical Rainforest, embracing high biodiversity and a vast flooding area. This region has been converted to agricultural lands since 1970 s, for the past four decades, leading to a fragmented landscape that holds one of the few large remaining blocks of Cerrado primary vegetation. Therefore, to assess the degree of preservation of this area a 2007 primary vegetation map was derived through Boolean operations using land use and land cover maps from 1975, 1985, 1996 and 2007, from digital classification of Landsat MSS and TM images. To evaluate the role of driving factors on the presence of pristine vegetation, a logistic regression analyses was performed. Tested factors were: distance from roads and cities, terrain slope, land tenure, soil fertility and flooding. We found statistical significant values $(p<.05)$ showing that distance from roads and cities, the increase in slope, the presence of protected areas, indigenous lands, wetlands and areas with low fertility have positive influence on the presence and maintenance of these pristine areas. The occurrence of original vegetation in many cases is associated with environmental constraints that difficult or do not allow agricultural use. Analysis of physical and political factors, which may have direct or indirect influence on the conservation and degradation of native vegetation are very important for the comprehension of the dynamics of regional land use, and provide supporting information for a more efficient and sustainable regional landscape planning.
\end{abstract}

Keywords: Amazon-Cerrado Transition; Pristine Vegetation; Driving Factors; Deforestation; Araguaia River Basin; Regional Planning

\section{Introduction}

The expansion of agricultural frontier in the tropics has been identified as one of the main drivers of deforestation (Alves et al., 2009; Geist \& Lambin, 2001). In Brazil, since 1980s, although Savanna biome (locally known as Cerrado) has been converted to agricultural lands at higher rates than those found for the Amazon, most of the attention to the consequences of land use and land cover change has been focused in Tropical Rain Forest ecosystems (Alves et al., 1999; Batistella \& Moran, 2005; Cardille \& Foley, 2003; Fearnside, 2006; Laurance et al., 2004; Mahar, 1989).

Spatially, forest clearance in Brazilian Amazon has been mainly concentrated at the deforestation arc (Ferreira et al., 2005), encompassing the south, east and west boundaries of the Tropical Rain Forest and a transition zone between this biome and the Cerrado. This transition zone includes about 600 hundred $\mathrm{km}^{2}$ of savannas located in the drainage basins of Tocantins and Araguaia Rivers. Since 1970s, intense farming activities, agricultural expansion and inappropriate land management have already resulted in active erosion at the head waters of the Araguaia River Basin, causing indirect impacts at the middle portion of the basin (Latrubesse \& Stevaux, 2006; Coe et al., 2011). Due to its high biodiversity and vast flooding area, the alluvial zone of the Araguaia and the Bananal lowland regions were identified by the Brazilian Ministry of Environment as a priority area for conservation (MMA, 2010). Nevertheless, only few studies about the degree of conservation of the natu- ral vegetation have been carried out in this region.

Conservation of the Araguaia-Bananal area, as well as other Cerrado large areas, is mainly related to regions where there is at least one factor preventing agriculture expansion, such as terrain slope, shallow soils and flooded areas (Machado et al., 2004). As a complex phenomenon, the origin of deforestation can be attributed to a series of factors (Alencar et al., 2004), related to local, regional and global scale processes. In the Amazon, many studies have shown that increasing in deforestation was related to tax incentives (Mahar, 1989; Nepstad et al., 2001), national economy (Alencar et al., 2004), wood industry, agriculture and cattle raising expansion (Alencar et al., 2004; Asner et al., 2009; Margulis, 2004; Walker et al., 2009), roads construction (Alves et al., 2009; Ballester et al., 2003), low slope, soil properties, among others. In this scenario, an important strategy to decrease deforestation is the public conservation policies aiming the creation of conservation units of integral preservation, sustainable use of natural resources and indigenous lands (Alencar et al., 2004).

Most studies about drive factors are focused on deforestation processes and there is a lack of information concerning what factors are responsible for preventing native vegetation losses. Therefore, the main objectives of this study were: 1) identify and quantify pristine vegetation in the middle Araguaia River basin and 2) analyze the influence of roads, cities, slope, land tenure, soil fertility, and flooding regime in the occurrence of primary vegetation remnants. 


\section{Methods}

\section{Study Area}

The Araguaia River is part of the Araguaia-Tocantins Basin, draining areas of Tropical Rain Forest and Cerrado biomes, and considered one the South America most important riverine and wetland system (ANA, 2008). The study area covers 166,000 $\mathrm{km}^{2}$, located in the central portion of the Araguaia River Basin, in central Brazil. This area encompasses part of the Tocantins, Mato Grosso, Pará and Goiás States, in the transition zone between Tropical Rain Forest and Cerrado, covering three quarters of the studied landscape (Figure 1). The natural heterogeneity of vegetation physiognomies, associated with increasing human disturbances, generated a complex dynamic change in native vegetation structure and configuration of the landscape.

The main Cerrado physiognomies found in the study area are: Grasslands, Shrublands and Forestlands, whereas dominant forest physiognomies are Open Rainforest (IBGE, 2004) and Transitional Forest, which is the most threatened physiognomy in Amazon. Its continuous loss has raised concerns, not only because of its ecological value (still poorly known), but also due to its open structure that makes it more susceptive to fires (Alencar et al., 2004).

The Araguaia is one of the main river basin draining the Cerrado biome, and includes the most important wetland of Central Brazil (Latrubesse et al., 2009), a quaternary alluvial lowland well developed and extending for more than $1100 \mathrm{~km}$ from Registro do Araguaia to Conceição do Araguaia (Carvalho et al., 2009; Latrubesse \& Stevaux, 2006). In the northern part of this sedimentary basin is located the Bananal island, the largest fluvial island of the world. During the rainy season, a vast area of the Bananal plain is flooded. The vegetation is dominated by Grasslands and Riparian Forest, and in higher zones by Cerrado Woodland and Alluvial Forest (Diegues, 2002). Livestock is the dominant economic activity in this region, where productive areas can be planted or natural pastures. The native grasslands in the flooded areas of the Bananal lowland maintain a reasonable capacity for cattle rising during the dry season (Diegues, 2002).

The climate of the study area is warm and seasonally humid,

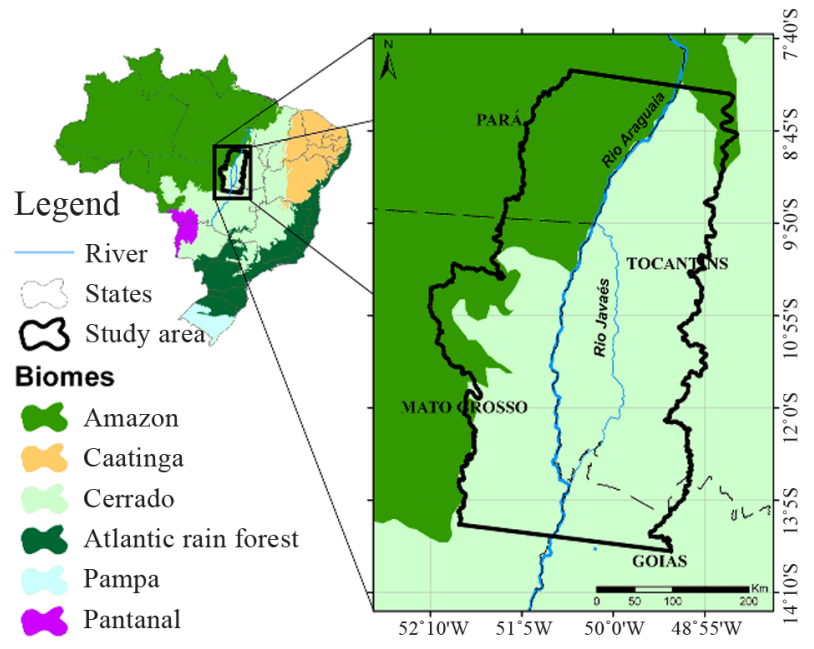

Figure 1.

Localization of the study area in the middle Araguaia River basin and the biomes that the area encompasses. with an annual mean precipitation of $1755 \mathrm{~mm}$ and mean monthly temperatures ranging from $25.1^{\circ} \mathrm{C}$ in January to $26.4^{\circ} \mathrm{C}$ in September. The dry season is from May to September (mean relative humidity of $40 \%$ ), while the wet season is from October to April (mean relative humidity of 90\%) (Borma et al., 2009). Plinth and Concretionary soils are the dominant soil types of the region, where can also be found Hydromorphic soils, Ox soils and Quartz sands (SEPLAN, 2008). The first two types present agricultural limitation due to low drainage and presence of ferruginous concretion, respectively (Coutinho, 2005).

\section{Primary Vegetation Mapping}

A 2007 primary vegetation map was derived through Boolean operations using land use and land cover maps from 1975, 1985, 1996 and 2007. These maps were obtained from Landsat Multispectral Scanner (MSS) for 1975 and Thematic Mapper (TM) for other years. Images were processed in ERDAS-IMAGE (version 9.2) using hybrid classification, composed by an unsupervised followed by a supervised methodology ( $\mathrm{Yu} \& \mathrm{Ng}$, 2006). The accuracy assessment was performed for 2007 by calculating overall accuracy and Kappa index using 287 ground truth points. The classification was considered good, with an overall accuracy of $85.02 \%$ and overall Kappa statistics of 0.75 .

Native vegetation was separated in three different classes, defined according to the vegetation structure: 1) Forest, comprehending Dry Forest, Wooded Cerrado and Riparian Forest; 2) Cerrado Grassland, including all grassland dominated physiognomies and 3) Cerrado Woodland for shrubs dominated areas. To generate the final map, the three classes for each date were reclassified into one, called native vegetation. Finally, a simple Boolean operation was employed to select those areas of unchanged cover until 2007, eliminating re-growth regions. The 2007 native vegetation map was used to mask the different classes of native vegetation again, resulting in a map of pristine Forest, Cerrado Grassland and Cerrado Woodland remnants in 2007.

\section{Driving Factors for Native Vegetation Conservation}

The presence of native vegetation in Amazon is mainly motivated by isolation and existence of protected areas (Bruner et al., 2001), while deforested regions are related to roads and cities proximity (Alves et al., 1999; Ballester et al., 2003; Batistella \& Moran, 2005). Therefore, to identify drivers of pristine vegetation remnants in our study area, we selected six factors: 1) roads distances; 2) cities distances; 3) terrain slope; 4) land tenure; 5) fertility; and 6) presence of flooding areas (Figure 2). Due to Landsat-MSS cell resolution we standardized the spatial resolution of all grid cell maps in 80 meters.

Roads, cities and fertility maps were obtained from a digital library available at IBAMA Remote Sensing Center (http://siscom.ibama.gov.br/sitecsr/). We used only state and federal roads, totalizing $3350 \mathrm{~km}$, of which $1884 \mathrm{~km}$ are paved. Roads and cities distance maps were derived by calculating the Euclidean distance perpendicular to them (Figures 2(a) and (b)). Due to high distance values, their distribution were corrected by applying a logarithmic transformation (Serneels \& Lambin, 2001).

The slope map, in percent, was derived from a Digital Elevation Model obtained by processing Shuttle Radar Topographic 

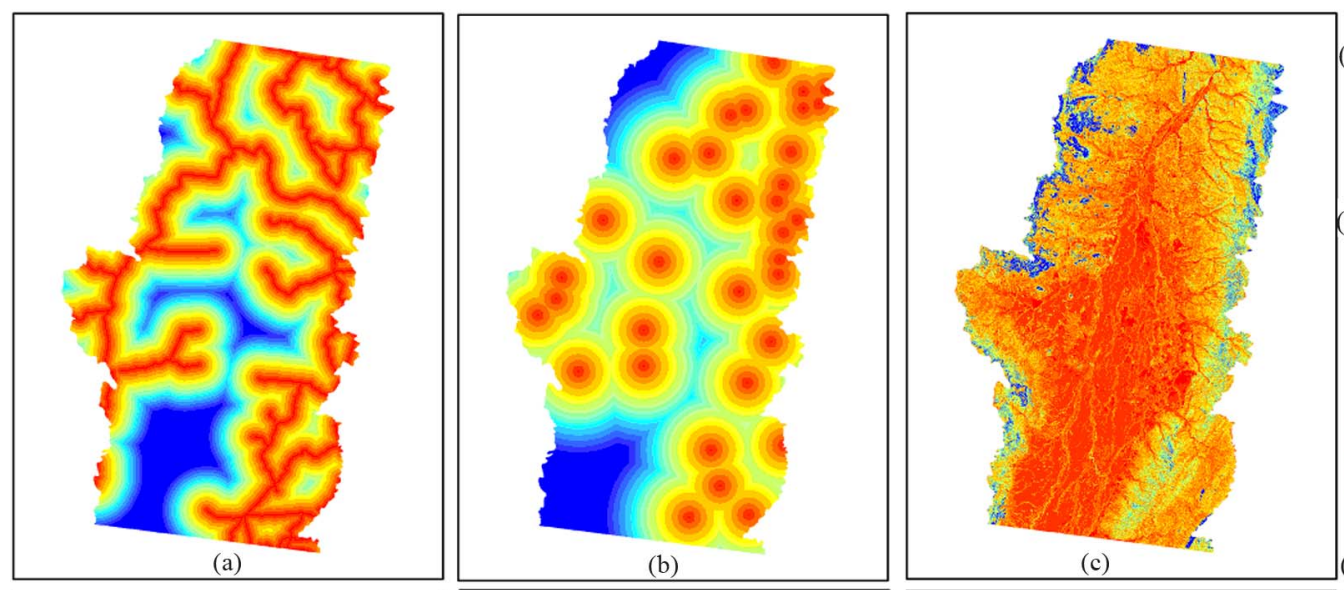

(a) Distance to roads (m)

High: 90539.5

Low: 0

(b) Distance to cities (m)

High: 180441

Low: 0

(c) Slope (\%)

High: 129.933

Low: 0
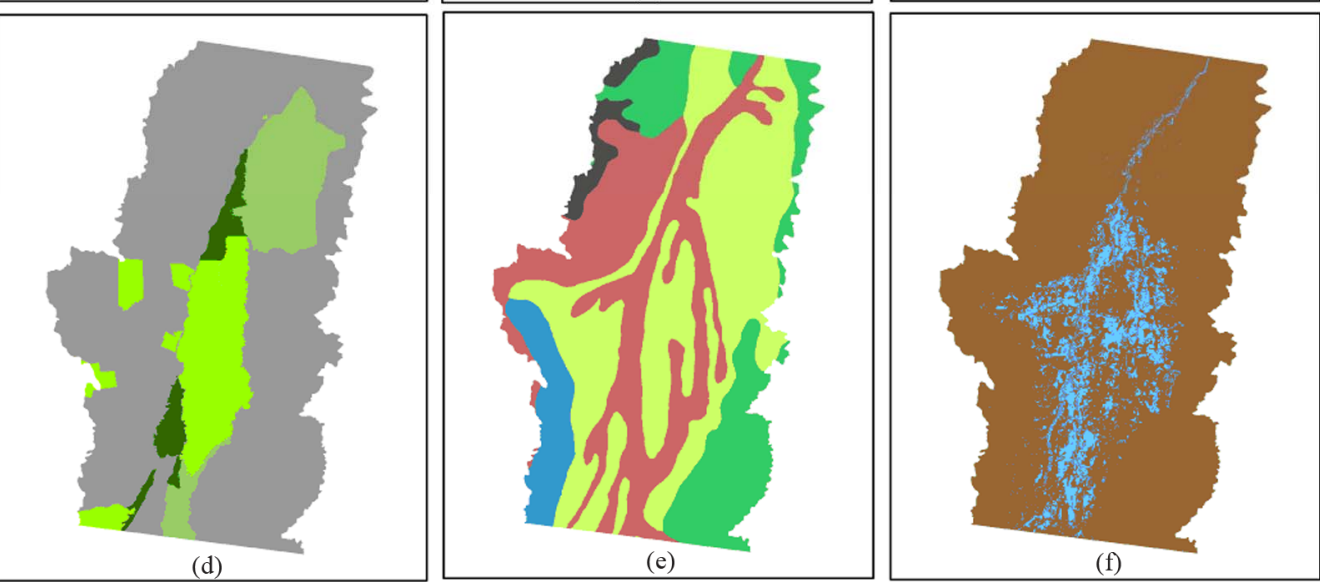

(d) Land tenure

igure 2.

Analyzed factors maps that can influence the occurrence of primary native vegetation in the middle Araguaia River basin: (a) Distance to roads; (b) Distance to cities; (c) Slope; (d) Land tenure; (e) Fertility; and (f) Presence of flooding areas.

Mission (SRTM) data from EMBRAPA satellite monitoring unit (www.relevobr.cnpm.embrapa.br). As shown in Figure 2(c), there is an extensive flat area dominating the south and central part of the landscape, and areas with high slope concentrated in northwest and northeast regions.

Land tenure map encompasses private lands, indigenous land, state and federal conservation units-divided into integral protection (State and National Parks, and Wildlife Refuge) and sustainable for use (Environmental Protection Areas). Data were downloaded from a digital library available at the Brazilian Ministry of Environment (http://www.mma.gov.br/sitio/ index.php).

The majority of conservation units and indigenous lands of the Araguaia basin are located in the study area and cover around $30 \%$ of the area (Figure 2(d)). To calculate coefficients of Land Tenure classes, private areas were used as reference.

Soil fertility data were obtained from the agricultural suitability map of Brazil (IBAMA dataset, http://siscom.ibama.gov. $\mathrm{br} /$ sitecsr/). In general, soils in the study area are dominated by low fertility classes. The dominant class was "Very low fertility" to "Low fertility", localized in the central zone from south to north. The second dominant class was "Low fertility", concentrated along the main rivers and in the west side of the study area (Figure 2(e)). The reference class used for soil fertility coefficients calculations was "Low", an intermediate class, allowing the visualization of higher and lower classes.
The flooded areas map was extracted from the South America Vegetation Map developed by Eva et al. (2002). These areas are concentrated in the central portion of the study region, encompassing over 17,480 $\mathrm{km}^{2}$ (Figure 2(f)). In this case nonflooded area was used as reference for the calculation.

\section{Statistical Analyzes}

To determine the influence of each factor on the presence or absence of primary vegetation, a binary logistic regression analysis was performed using the maximum likelihood method in Minitab software, with $p$-value coefficients lower than 0.05 . This analysis estimates the coefficient value, standard deviation and $p$ value for each variable, indicating the effect (positive or negative) that each predictive variable has on a response variable. Furthermore, for categorical data are possible to verify the weight that each variable class has in relation to the presence of primary vegetation. As these analyses only test binary variables, the native cover classes were grouped in one class showing the presence or absence of native vegetation.

Data sampling was carried on using 50,000 random points distributed in the study area with a minimal distance of $100 \mathrm{~m}$ from each other, avoiding sampling in the same pixel (Chomitz \& Gray, 1996; Mertens \& Lambin, 2000; Serneels \& Lambin, 2001; Ugon, 2004). These points were used to extract the information from all maps and build a matrix. 


\section{Results}

Pristine vegetation in 2007 comprised an area of $86,800 \mathrm{~km}^{2}$, which is equivalent to $52.3 \%$ of the study area. This vegetation was mainly concentrated at the central portion of the landscape, where an extensive area of Cerrado Grassland was found. Cerrado Woodland areas occurred mainly along the edges of Cerrado Grassland, and were concentrated at the east and southwest regions. Despite the fact that the original area of forest extended from the north to the southwest border, larger remnants patches were denser in the central part of the landscape (Figure 3).

Forest was the dominant physiognomy, encompassing 25\% $\left(41,430 \mathrm{~km}^{2}\right)$ of the landscape, followed by Cerrado Grassland and Cerrado Woodland, covering $16.6 \%\left(27,640 \mathrm{~km}^{2}\right)$ and $10.7 \%\left(17,732 \mathrm{~km}^{2}\right)$ of the study area, respectively (Figure 4).

Table 1 presents the results from the logistic regression model applied to evaluate how some regional factors influence

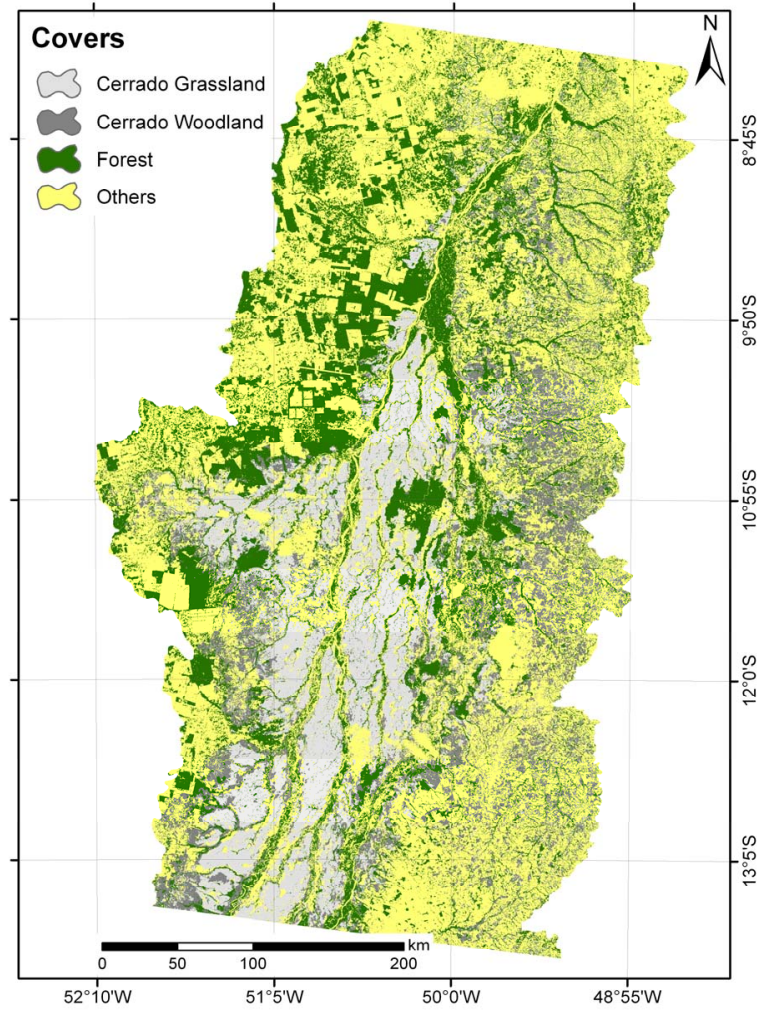

Figure 3.

Primary vegetation map in the middle Araguaia River basin in 2007.

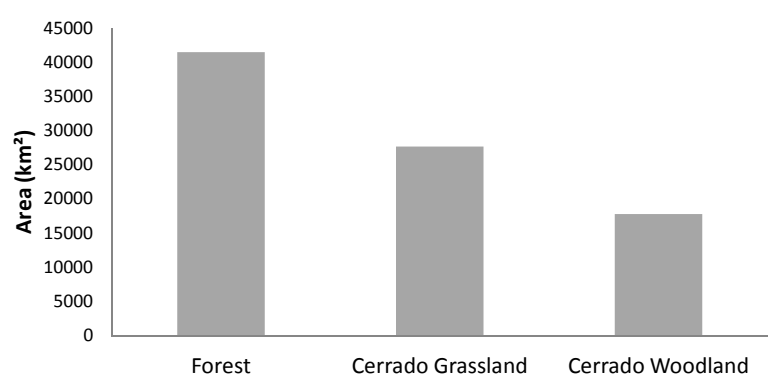

Figure 4.

Area covered for each physiognomy of native vegetation.
Table 1.

Coefficients values of the factors involved with presence and absence of primary native vegetation and its effect in the maintenance of this vegetation.

\begin{tabular}{cccc}
\hline Predictor & Coefficient & $\boldsymbol{p}$ & Effect \\
\hline Distance from Roads & 0.314 & 0.00 & Positive \\
Distance from Cities & 0.130 & 0.00 & Positive \\
Slope & 0.019 & 0.00 & Positive \\
Land Tenure & & & \\
Integral Protection & 0.878 & 0.00 & Positive \\
Indigenous Land & 0.622 & 0.00 & Positive \\
Sustainable Use & 0.054 & 0.08 & - \\
Fertility & & & \\
Low to Medium & -0.478 & 0.00 & Negative \\
Medium & -0.638 & 0.00 & Negative \\
Very Low & 0.025 & 0.55 & - \\
Very Low to Low & 0.354 & 0.00 & Positive \\
Flooded Area & & & \\
Flooded & 0.291 & 0.00 & Positive \\
\hline
\end{tabular}

For categorical data as Land tenure, Fertility and Flooded area the calculation of each class was done using private areas, Low fertility, and non-flooded areas, respectively, as reference.

the maintenance the amount of primary vegetation still remaining in the middle Araguaia River basin. Terrain physical characteristics, evaluated as slope and soil fertility, have an opposite effect on the presence of primary vegetation. A positive relationship was found between slope increase and presence of forest. While flatter areas are preferred for implementation of agricultural crops, remnants of forest tended to concentrate at steeper areas (Coefficient 0.019) (Figure 5(a)). In contrast, soil fertility had a negative impact on native vegetation cover. Areas with more fertile soil are preferable for agricultural practices and therefore, pristine vegetation remnants concentrate on very low to low fertility soils (Coefficient 0.354 ). These soils were cover by $22 \%$ of the remaining Forest, $25 \%$ of the Cerrado Grassland and 13\% of the Cerrado Woodland areas (Figure 5(b)).

Natural flooding events affected about $10 \%$ of the study area and have a positive influence in the maintenance of pristine areas (Coefficient 0.291). Of the extent of flooded systems $\left(17,400 \mathrm{~km}^{2}\right) 71 \%$ were cover by natural vegetation, with Forest encompassing $18 \%$ and Cerrado $53 \%$. In private lands found in these ecosystems, agriculture and pasture areas covered $31 \%$, since they are less suitable for agricultural practices (Figure 5(c)).

The evaluation of the role of land tenure showed that the presence of conservation units of integral protection and indigenous lands had a positive influence on primary vegetation and presented the higher coefficient values, 0.878 and 0.622 , respectively. Of the total remaining natural vegetation in 2007 , $27 \%$ of Forest, $41 \%$ of Cerrado Grassland and $13 \%$ of Cerrado Woodland were found in these areas (Figure 5(d)).

Distance from roads and cities showed an expected pattern of 

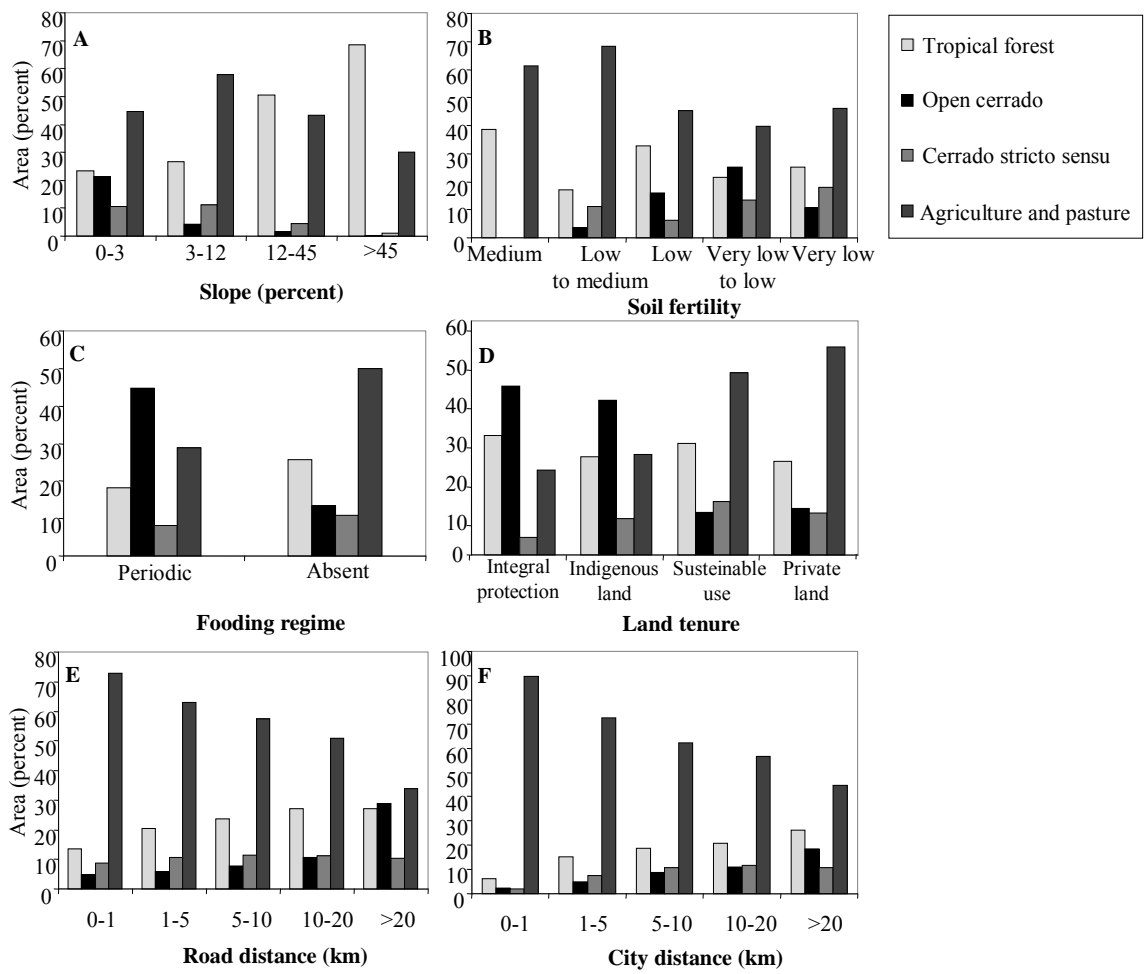

Figure 5.

Relative contribution of land cover and land use areas for each analyzed factor classes.

positive influence in the presence of primary vegetation. Larger areas covered with native forest are found as the distance from roads increases (Coefficient 0.314); of the total Forest remnants, $70 \%$ were at least at $10 \mathrm{~km}$ from a road, while for Cerrado Grassland and Cerrado Woodland this value was $86 \%$ and $66 \%$, respectively. A similar pattern was found for distance from cities, but the lower coefficient value (0.130) indicates a less intense relationship (Figures 5(e) and (f)).

\section{Discussion}

In Brazilian Amazon, deforestation is primarily related to road development (Laurance et al., 2002) and governmental colonization programs (Alves et al., 1999; Batistella \& Moran, 2005; Ferreira et al., 2007). Moreover, infrastructure implementation and government policy are the primary drivers controlling time and spatial scales of deforestation in most cases (Ballester et al., 2003). In general, this process begins with official or unofficial roads opening and paving in a preserved region, which in turn allow access to illegal wood exploitation, followed by conversion to pasture for cattle and crops (Ferreira et al., 2005; Yoshikawa \& Sanga-Ngoie, 2011). Previous studies in the Amazon region have shown that deforestation is more intense and concentrated near roads, with up to $90 \%$ of forest clearing occurring within a $20 \mathrm{~km}$ buffer from a road (Ballester et al., 2003; Ferreira 2001; Gils \& Ugon, 2006; Kirby et al., 2006; Ludeke et al., 1990; Nepstad et al., 2001), suggesting their influence in the increase of land cover conversion.

Road network construction and highway modernization are the main threats to preservation of large areas of pristine vegetation, facilitating access to logging, migration and farming (Primack, 2002). The simple announcement of roads opening or improvements usually generates a speculative land rush that consequently can lead to a significant deforestation increase (Fearnside, 2006). Results from several modeling studies using this scenario (Ferreira et al., 2005; Laurance et al., 2001; Soares et al., 2004; Soares-Filho et al., 2005) have shown that public policy to control deforestation and land use planning play a key role in reducing the impact of roads construction and improvement on native vegetation.

Despite the fact that urban center proximity has a negative impact in forest preservation, its influence showed a different spatial effect on primary vegetation remnants distribution. While distance from roads presented a large effect in recent deforestation, our statistical analysis shows that distance from an urban center was more important at clearing initial stages, when nearer areas were preferred due to their proximity (Mertens \& Lambin, 2000). This pattern emerges in areas located at cities closer surroundings. When these surroundings are occupied for agriculture and livestock activities, it is necessary to go increasingly far through roads, which in turn increases their influence in deforestation. In general, distance from roads and cities tend to have high correlation with deforestation and the presence of primary vegetation remnants, since the increase of migration, emergence and growth of urban areas are dependent on existing roads linking cities and facilitating agricultural production flow to other consumers markets.

The positive influence of slope can be associated with the major economic activity of the region, cattle rising, which dominates in planted and native pastures in low slope regions of the landscape. Nevertheless, during field surveys we were able to determinate that native pastures grow in moderate slope areas, as well as in flat flooded regions, resulting in the low observed coefficient value. Moreover, even in some cases in 
which land cover of these portions of the landscape has not changed, they have been impacted by human use and management practices of native pastures. A significant relationship between forest conversion in flat and not flooded areas was found for tropical forest conversion in Bolivia (Ugon, 2004). However, topography was irrelevant in forest conversion prediction models because road influence is stronger than the barrier effect of high slope (Gils \& Ugon, 2006), reinforcing the weight that new roads have on deforestation.

Integral protection areas were the most effective for conservation. Similar pattern was observed for Peruvian Amazon (Oliveira et al., 2007). The low coefficient value of the "sustainable use" class was related to the agricultural and pasture use allowed in these conservation units. For the study area, the sustainable use class is equivalent to what is classified in Brazil as Environmental Protection Areas, which enables human occupation and is one of the less restrictive types of conservation unit in the National System of Conservation Units (Brasil, 2002). However, a high $p$-value $(0.08)$ does not enable any consideration about the coefficient value of this class. The proportion of deforested areas within protected areas, such as conservation units of integral protection, sustainable use and indigenous land, was lower than outside them, indicating their importance as mechanisms to hold or slow down deforestation processes. The same pattern was found in other tropical areas. For instance, in Belize low rates of deforestation were found within the limits of national parks (Chomitz \& Gray, 1996), while in Bolivia was verified that land with owners tend to be less invaded by settlers, preventing illegal occupation and consequently deforestation (Gils \& Ugon, 2006).

As expected, logistic regression values showed a pattern in which the best fertility classes of the region have a negative influence in the presence of primary vegetation, while lower fertility classes have a positive influence in their maintenance. Although such pattern was expected, with the advance of agricultural techniques, large areas previously inappropriate for agriculture have now become available (Gils \& Ugon, 2006). The class "Very low" was not considered due to its high $p$-value $(0.55)$, which can be attributed to various mixtures of land cover classes in areas within this fertility class.

The Araguaia sedimentary plain is considered the most promising area for expansion of rice cropping in Brazil (EMBRAPA, 2008). The surroundings of Bananal Island, called Javaés Valley, were regarded as particularly suitable for this culture (Collicchio, 2008), and already have irrigation projects to produce different agricultural crops (Collicchio, 2006). Although all these projects have resulted in the conversion of large areas of native vegetation, which are adapted to the flooding regime, the occurrence of flooding have a positive influence in the maintenance of pristine vegetation. Nevertheless, this result can be related to land tenure, which could have a strong effect over this variable due to the overlap of indigenous land and integral protection conservation units with flooded areas, preventing the implantation of agricultural projects.

The effectiveness to preserve native vegetation within conservation units is not always easily achieved because deforestation will be greater if parks are closer to the capital cities, in sites closer to federal roads and on lower slopes (Pfaff et al., 2009). In some cases, the presence of pristine areas can be associated not only with conservation units but also with the local characteristics where they were created. Areas naturally protected from human exploration, such as remote places, steep areas, poor soils, flooded wetlands and any other factor that makes agriculture more difficult can be more important factors than the delimitation of conservation units. In these cases, it is not trivial to evaluate the real importance of the delimited protected areas (Joppa et al., 2008). In our particular case of study, the landscape was predominantly flat, with a large road network, and several protected areas, which are located mainly in wetlands and also on low fertility soils. The overlap of all these factors makes difficult to isolate the role of each factor, and hence its effectiveness in native vegetation conservation.

Other studies have shown a high and statistically significant influence of land tenure and distance from roads on the prediction of forest conversion. Distances from villages and topography have a smaller contribution while no significant predictive value was found for soil types (Gils \& Ugon, 2006). Our results show that the presence of primary vegetation is linked in some extent to all tested drivers. Environmental constraints, inherent to the area, may be the factor responsible for making more demanding or precluding the conversion of primary vegetation into agricultural areas. Hilly slopes or wetlands areas can act as factors that hinder or even make impossible the transport of products for consumer markets due to high transportation costs (Chomitz \& Gray, 1996). These local characteristics are also a limiting factor for mechanized agriculture, which has a preference for flat areas, where machinery access is facilitated. This feature is more important than soil quality, which can be improved with fertilizers (Serneels \& Lambin, 2001).

\section{Conclusion}

Our analysis of all these variables showed that the presence of primary vegetation can be associated with different environmental constraints, making more demanding or preventing land conversion. The main factors responsible for the maintenance of pristine vegetation are the presence of protected areas and environmental constraints. Moreover, understanding the role of physical and political factors, which may have (direct and indirect) influence on the deforestation or maintenance of native vegetation are key elements to better accesses land use dynamic and provide supporting information for a more efficient and sustainable regional planning.

\section{Acknowledgements}

Funding and scholarship for this study were provided by FAPESP and Milenio/CNPq (proc. 2003/13172-2, 2007/016862 and 420199/2005-5, respectively). The third author received support from United States National Aeronautics and Space Administration (NASA) - Land-Cover and Land-Use Change Program (LCLUC) (NNX11AE56G).

\section{REFERENCES}

Alencar, A., Nepstad, D., McGrath, D., Moutinho, P., Pacheco, P., Diaz, M. D. C. V. et al. (2004). Desmatamento na Amazônia: Indo além da emergência crônica. Belém: Instituto de Pesquisa Ambiental da Amazônia (Ipam).

Alves, D. S., Morton, D. C., Batistella, M., Roberts, D. A., \& Souza Jr., C. (2009). The changing rates and patterns of deforestation and land use in Brazilian Amazonia. In M. Keller, M. Bustamante, J. Gash, \& P. S. Dias (Eds.), Amazonia and global change (pp. 11-24). Washington DC: American Geophysical Union. doi:10.1029/2008GM000722

Alves, D. S., Pereira, J. L. G., De Sousa, C. L., Soares, J. V., \& Yama- 
guchi, F. (1999). Characterizing landscape changes in central Rondonia using Landsat TM imagery. International Journal of Remote Sensing, 20, 2877-2882. doi:10.1080/014311699211859

Asner, G. P., Keller, M., Lentini, M., Merry, F., \& Souza Jr., C. (2009). Selective logging and its relation to deforestation. In M. Keller, M. Bustamante, J. Gash \& P. S. Dias (Eds.), Amazonia and global change (pp. 25-42). Washington DC: American Geophysical Union. doi:10.1029/2008GM000723

Ballester, M. V. R., Victoria, D. D., Krusche, A. V., Coburn, R., Victoria, R. L., Richey, J. E. et al. (2003). A remote sensing/GIS-based physical template to understand the biogeochemistry of the Ji-Parana river basin (Western Amazonia). Remote Sensing of Environment, 87, 429-445. doi:10.1016/j.rse.2002.10.001

Batistella, M., \& Moran, E. F. (2005). Dimensões humanas do uso e cobertura das terras na Amazônia: uma contribuição do LBA. Acta Amazonica, 35, 239-247. doi:10.1590/S0044-59672005000200014

Borma, L. S., da Rocha, H. R., Cabral, O. M., von Randow, C., Collicchio, E., Kurzatkowski, D. et al. (2009). Atmosphere and hydrological controls of the evapotranspiration over a floodplain forest in the Bananal Island region, Amazonia. Journal of Geophysical Research, 114, Article ID: G01003.

Bruner, A. G., Gullison, R. E., Rice, R. E., \& da Fonseca, G. A. B. (2001). Effectiveness of parks in protecting tropical biodiversity. Science, 291, 125-128. doi:10.1126/science.291.5501.125

Cardille, J. A., \& Foley, J. A. (2003). Agricultural land-use change in Brazilian Amazonia between 1980 and 1995: Evidence from integrated satellite and census data. Remote Sensing of Environment, 87, 551-562. doi:10.1016/j.rse.2002.09.001

Carvalho, F. M. V., De Marco Júnior, P., \& Ferreira, L. G. (2009). The Cerrado into-pieces: Habitat fragmentation as a function of landscape use in the savannas of central Brazil. Biological Conservation, 142, 1392-1403. doi:10.1016/j.biocon.2009.01.031

Chomitz, K. M., \& Gray, D. A. (1996). Roads, land use, and deforestation: A spatial model applied to belize. World Bank Economic Review, 10, 487-512. doi:10.1093/wber/10.3.487

Collicchio, E. (2006). Organização estadual de pesquisa agropecuária: Um instrumento de apoio ao desenvolvimento rural sustentável do Tocantins. Palmas: Provisão.

Collicchio, E. (2008). Zoneamento edafoclimático e ambiental para a cana-de-açúcar e as implicações das mudanças climáticas no estado do Tocantins. Ph.D. Thesis, Piracicaba: University of São Paulo.

Coutinho, A. C. (2005). Dinâmica das queimadas no estado do Mato Grosso e suas relações com as atividades antrópicas e a economia local. Ph.D. Thesis, São Paulo: University Of São Paulo.

Diegues, A. C. S. (2002). Povos e águas: Inventário de áreas úmidas (2 ed.). São Paulo: Núcleo de apoio à pesquisa sobre populações humanas e áreas úmidas, USP.

EMBRAPA (2008). Informações técnicas para a cultura do arroz irrigado no Estado do Tocantins: Safra 2008/2009. Santo Antônio de Goiás: EMBRAPA Arroz e Feijão.

Fearnside, P. M. (2006). Desmatamento na Amazônia: Dinâmica, impactos e controle. Acta Amazonica, 36, 395-400. doi:10.1590/S0044-59672006000300018

Ferreira, L. V. (2001). Identificação de áreas prioritárias para a conservação da biodiversidade por meio da representatividade das unidades de conservação e tipos de vegetação nas ecorregiões da Amazônia brasileira. In J. P. R. Capobianco (Ed.), Biodiversidade na Amazônia brasileira: Avaliação e ações prioritárias para a conservação, uso sustentável e repartição de benefícios (pp. 268-286). São Paulo: Instituto Socioambiental.

Ferreira, L. V., Venticinque, E., \& Almeida, S. (2005). O desmatamento na Amazônia e a importância das áreas protegidas. Estudos Avançados, 19, 157-166. doi:10.1590/S0103-40142005000100010

Ferreira, N. C., Ferreira, L. G., \& Miziara, F. (2007). Deforestation hotspots in the Brazilian Amazon: Evidence and causes as assessed from remote sensing and census data. Earth Interactions, 11, 1-16. doi:10.1590/S0044-59672006000300018

Geist, H. J., \& Lambin, E. F. (2001). What drives tropical deforestation? A meta-analysis of proximate and underlying causes of deforestation based on subnational case study evidence. Belgium: University of
Louvain.

Gils, H. A. M. J. V., \& Ugon, A. V. L. A. (2006). What drives conversion of tropical forest in Carrasco province, Bolivia? Ambio, 35, 8185. doi:10.1579/0044-7447(2006)35[81:WDCOTF]2.0.CO;2

Joppa, L. N., Loarie, S. R., \& Pimm, S. L. (2008). On the protection of "protected areas". Proceedings of the National Academy of Sciences of the United States of America, 105, 6673-6678. doi: $10.1073 /$ pnas. 0802471105

Kirby, K. R., Laurance, W. F., Albernaz, A. K., Schroth, G., Fearnside, P. M., Bergen, S. et al. (2006). The future of deforestation in the Brazilian Amazon. Futures, 38, 432-453. doi:10.1016/j.futures.2005.07.011

Latrubesse, E. M., Amsler, M. L., de Morais, R. P., \& Aquino, S. (2009). The geomorphologic response of a large pristine alluvial river to tremendous deforestation in the South American tropics: The case of the Araguaia River. Geomorphology, 113, 239-252. doi:10.1016/j.geomorph.2009.03.014

Latrubesse, E. M., \& Stevaux, J. C. (2006). Características físico-bióticas e problemas ambientais associados à planície aluvial do rio Araguaia, Brasil central. Revista UnG-Geociências, 5, 65-73.

Laurance, W. F., Albernaz, A. K. M., Fearnside, P. M., Vasconcelos, H. L., \& Ferreira, L. V. (2004). Deforestation in Amazonia. Science, 304, 1109b-1111b. doi:10.1126/science.304.5674.1109b

Laurance, W. F., Albernaz, A. K. M., Schroth, G., Fearnside, P. M., Bergen, S., Venticinque, E. M. et al. (2002). Predictors of deforestation in the Brazilian Amazon. Journal of Biogeography, 29, 737-748. doi:10.1046/j.1365-2699.2002.00721.x

Laurance, W. F., Cochrane, M. A., Bergen, S., Fearnside, P. M., Delamonica, P., Barber, C. et al. (2001). The future of the Brazilian Amazon. Science, 291, 438-439. doi:10.1126/science.291.5503.438

Ludeke, A. K., Maggio, R. C., \& Reid, L. M. (1990). An analysis of anthropogenic deforestation using logistic regression and GIS. Journal of Environmental Management, 31, 247-259. doi:10.1016/S0301-4797(05)80038-6

Machado, R. B., Ramos Neto, M. B., Pereira, P. G. P., Caldas, E. F., Gonçalves, D. A., Santos, N. S. et al. (2004). Estimativas de perda da área do Cerrado brasileiro. Conservação Internacional.

Mahar, D. J. (1989). Government policies and deforestation in Brazil's Amazon region. Washington: World Bank Publications.

Margulis, S. (2004). Causas do desmatamento da Amazonia Brasileira. Brasília: Banco Mundial.

Mertens, B., \& Lambin, E. F. (2000). Land-cover-change trajectories in southern Cameroon. Annals of the Association of American Geographers, 90, 467-494. doi:10.1111/0004-5608.00205

Nepstad, D., Carvalho, G., Cristina Barros, A., Alencar, A., Paulo Capobianco, J., Bishop, J. et al. (2001). Road paving, fire regime feedbacks, and the future of Amazon forests. Forest Ecology and Management, 154, 395-407. doi:10.1016/S0378-1127(01)00511-4

Oliveira, P. J. C., Asner, G. P., Knapp, D. E., Almeyda, A., Galvan-Gildemeister, R., Keene, S. et al. (2007). Land-use allocation protects the Peruvian Amazon. Science, 317, 1233-1236. doi:10.1126/science. 1146324

Pfaff, A., Robalino, J., Sanchez-Azofeifa, G. A., Andam, K. S., \& Ferraro, P. J. (2009). Park location affects forest protection: Land characteristics cause differences in park impacts across Costa Rica. B.E. Journal of Economic Analysis \& Policy, 9, 26. doi:10.2202/1935-1682.1990

Primack, R. B. (2002). Essentials of conservation biology (3.ed.). Sunderland: Sinauer Associates.

SEPLAN (2008). Atlas do Tocantins: Subsídios à gestão e planejamento territorial. Palmas: SEPLAN.

Serneels, S., \& Lambin, E. F. (2001). Proximate causes of land-use change in Narok District, Kenya: A spatial statistical model. Agriculture, Ecosystems \& Environment, 85, 65-81. doi:10.1016/S0167-8809(01)00188-8

Soares, B., Alencar, A., Nepstad, D., Cerqueira, G., Diaz, M. D. V., Rivero, S. et al. (2004). Simulating the response of land-cover changes to road paving and governance along a major Amazon highway: The Santarem-Cuiaba corridor. Global Change Biology, 10, 745-764. doi:10.2202/1935-1682.1990

Soares-Filho, B. S., Nepstad, D. C., Curran, L., Cerqueira, G. C., 


\section{H. O. SAWAKUCHI ET AL.}

Garcia, R. A., Ramos, C. A. et al. (2005). Cenários de desmatamento para a Amazônia. Estudos Avançados, 19, 137-152.

doi:10.1590/S0103-40142005000200008

Ugon, A. V. L. A. (2004). A spatial logistic model for Tropical forest conversion: A case study os Carrasco province (1986-2002), Bolivia. Master Thesis, Enschede: International Institute for Geo-Information Science and Earth Observation (ITC).

Walker, R., DeFries, R., Vera-Diaz, M. C., Shimabukuro, Y., \& Venturieri, A. (2009). The expansion of intensive agriculture and ranching in Brazilian Amazonia. In M. Keller, M. Bustamante, J. Gash, \& P. S.
Dias (Eds.), Amazonia and Global Change (pp. 61-82). Washington DC: American Geophysical Union. doi:10.1029/2008GM000735

Yoshikawa, S., \& Sanga-Ngoie, K. (2011). Deforestation dynamics in Mato Grosso in the southern Brazilian Amazon using GIS and NOAA/AVHRR data. International Journal of Remote Sensing, 32, 523-544. doi:10.1080/01431160903475225

Yu, X., \& Ng, C. (2006). An integrated evaluation of landscape change using remote sensing and landscape metrics: A case study of Panyu, Guangzhou. International Journal of Remote Sensing, 27, 1075-1092. doi: $10.1080 / 01431160500377162$ 